\title{
ANALYSIS OF SECURITY MANAGEMENT ACTIVITIES \\ AND ECONOMIC CONSEQUENCES OF CORRUPTION IN \\ PRIVATIZATION OF AGRICULTURAL LAND IN SERBIA
}

\author{
Stanimir Đukićl, Nenad Avramović ${ }^{2}$ \\ *Corresponding author E-mail: avramovic_vladimir@yahoo.com
}

A R T I C L E I N F O
Original Article
Received: 20 Febrary 2021
Accepted: 28 May 2021
doi:10.5937/ekoPolj2103595D
UDC 338.24.021.8:005.934
343.352:338.246.025.28]:712.2
4(497.11)

Keywords:

security management, privatization, corruption, economic consequences of corruption, privatization of agricultural land.

JEL: K11, K22, P2, Q10

\begin{abstract}
A B S T R A C T
Security management does not make strategic decisions, but it significantly influences their decision-making by providing top management with information and assessments on the basis of which strategic goals are defined and operational decisions are made. The paper also discusses the economic consequences of corruption in the privatization of agricultural land. The subject of the paper is privatization - a litmus test that clearly shows the strength of the Government's commitment to implement comprehensive reforms, primarily due to the consequences it causes in terms of social status and, more importantly, cultural patterns and way of thinking of the population. With privatization, the new owners would very often launder the money gained from criminal activities or would be interested only in acquiring attractive real estate, but not in preserving the production program, which led to a large number of fired workers and destroyed companies.
\end{abstract}

(C) 2021 EA. All rights reserved.

\section{Introduction}

Observing the protective function of the state through the system of the theory of the state, according to which the state has only one function, it is logical that there is no independent function of security. Accordingly, security can be defined as one of the activities. Along with it, economic, cultural and other activities are also mentioned (Stajic, 2011: 16).

Security management is a relatively new scientific discipline that emerged as a combination of management science and security science. In other words, security

1 Stanimir Đukić, Ph.D., Associate Professor, Faculty of Finance, Banking and Auditing, Alfa BK University, Palmira Toljatija Street no. 3, 11000 Belgrade, Serbia, Phone: +381 63216 681, E-mail: stanimirdj@hotmail.com, ORCID ID (https://orcid.org/0000-0003-1860-1560)

2 Nenad Avramović, Ph.D., Full professor, Faculty of Law, European University Brcko District, Bjeljinska cesta no. 72/74, 76100 Brcko, Bosnia and Hercegovina, Phone: +387 49590610 , E-mail: avramovic vladimir@yahoo.com, ORCID ID (https://orcid.org/0000-0003-0203-7627) 
management is the application of management procedures in the field of security (Dragisic, 2014:9). Modern security threats have made the interest in security much greater than ever in history, that is, the nature of modern security threats has imposed the need to address security issues and those organizations that have never had security in the scope of their work.

Given that corruption is a broad social problem, its consequences can have a great impact on the economic development of a country, but also on the development of the region as a whole. For that reason, the connection between corruption and the achieved level of economic development is often pointed out. This connection is mutual. The achieved level of economic development can be a factor and a cause of corruption. It can be said that poverty is one of the significant causes.

To consider corruption as the most dangerous form of organized crime, as Professor Mijalkovski states, it is advisable to keep in mind the position of the ancient Greek philosopher Aristotle, who reads: "The greatest crimes were not committed to obtain necessary, but superfluous", because corrupt people are public officials) without scruples, who abuse the indicated trust (Mijalkovski: 2012: 219).

After more than fifteen years of reforms, Serbia is practically at the beginning of the transition to a democratic society and market economy. Unlike the situation from the end of the 80's, the creators of economic policy in Serbia today have in front of them the experiences of countries in transition and the opportunity to choose those concepts of transition that have shown results.

Expectations of economic and social revival in most transition countries, and especially in Serbia, remained an unfulfilled wish, and "the process of transition, i.e. privatization as its central part, was accompanied by enormous structural disruptions, falling social product, falling employment, rising inflation, weakening state institutions, especially the judiciary through the disavowal of the law and the rise of corruption and crime." (Obradovic 2017: 41).

Privatization is a litmus test that clearly shows the strength of the Government's commitment to comprehensive reforms, primarily because of the consequences it has in terms of social status and, more importantly, the cultural pattern and way of thinking of the population. The history of privatization in Serbia, which is perhaps the most obvious confirmation of this thesis, is practically the history of the application of various models of free distribution of capital to employees, pensioners and citizens. However, the overall effects of privatization in Serbia until the democratic changes are minimal, primarily due to the lack of clear will of the then political elite in power to consistently implement reforms and transition to a market economy (Djukic, 2015: 271).

\section{Aim of the paper}

The main goal of this paper is to investigate the activities of security management and the economic consequences of corruption in the privatization of agricultural land in 
Serbia, i.e. the role and importance of state bodies in combating this serious problem, and preventing negative economic consequences for state property, budget and safety of legal order and economic business of the enterprise.

The aim of this paper is to reach conclusions about the existing social problems through an institutional analysis of the concept of corruption and certain specific cases in the period of transition in Serbia, and to try to offer a solution for them.

\section{Methodology}

The application of scientific research methods (description, classification, systematization, analysis-synthesis, induction-deduction, comparative analysis, descriptive statistics, case studies, historical method, etc.) has enabled a deeper and studious understanding of the causes, manifestations and economic consequences of corruption in privatization of agricultural land, as well as the role and powers of state bodies in combating corruption in order to obtain views on proposals for improving legal regulations, work and organization, as well as an attempt to build a methodological basis for such multidisciplinary research. Therefore, the goal was realized by applying known scientific methods, in which the following prevailed: comparative method and content analysis.

\section{Defining the term security management}

The word management itself comes from the English word manage, which means managing a company or public enterprise.

Management is a discipline that can be applied to different organizations. Management applied to the company represents the management of the company or business management, management applied to educational institutions is management in education, management in the police is called police management, management in public services is public management and the like. The basic principles of science management are applied to all areas of human work, while special methods and techniques of management are applied in each special organization, depending on its specificity. The basic task of the management of any organization is to increase the vitality of the organization, i.e. its ability to survive in different circumstances, with the prosperity and growth of the organization.

The term security management, in a broader sense, means deciding on the security goals of the organizational system, ways and means to avoid adverse impacts coming from the environment or the organizational system itself, or to reduce their harmful impact (Dragisic, 2014: 14).

The management of each organization pays special attention to security as a basic condition for survival and prosperity. Different organizations have different security challenges, risks and threats, so the risks to which the state as an organization is exposed differ greatly from the challenges to which a business enterprise or cultural institution 
is exposed. The various challenges, risks and threats to which an organization is exposed, as well as the responsibilities that the organization has towards the security environment, have a crucial impact on security management, i.e. the way in which security decisions will be made.

In this regard, in security organizations, special attention is paid to different theoretical sources of organization and management, as well as the possibility of applying different theories of management in solving organizational problems (Stevanovic, 2012: 51).

The way management deals with security issues, primarily depends on the overall goals of the organization. Thus, we can distinguish security management in organizations for which the provision of security services to other users is the basic mission, from security management in organizations engaged in economic or social activities and security management is in the function of preserving and growing the organization. In addition, there are companies that are of great importance for the safety of the community in which they operate, either because of the importance of their products and services for the normal life of the immediate or the wider community, or because of the dangerous forces contained in their plants and whose damage would cause great catastrophes.

In organizations that provide security services to other users, and these are, primarily, state security services, security management represent the basic, but not the only form of management, as such organizations perform a number of other functions (financial, planning, personnel, development, etc.). The situation is similar in private companies that provide security services to other organizations. The management of such companies must take into account the survival of such companies in the market, its development and growth, risks, challenges and threats that such companies face in the market, which actually makes the classic security management of any business company. In addition, depending on the level of services provided by the company, the managers of these companies participate in creating decisions related to security in other organizations, which, indirectly, makes them security managers of other organizations (Dragisic, 2014: 15). It should be emphasized that the most important decisions that determine the fate of the company are made from the managerial top, the so-called top management.

The success of operations in modern conditions largely depends on safety. Adverse security impacts that diminish the success of business organizations come from the environment and from the organizations themselves. Environmental influences range from adverse social influences, such as various political crises, wars, armed uprisings, terrorism and extremism, social tensions, etc., to natural disasters that can have a greater or lesser impact on business success. Intrusions of competition and various forms of economic subversion can range from infringement of intellectual property and copyright, spreading rumors, recruiting employees, revealing business secrets, to physical attacks on facilities where business functions are performed or on people working for that organization. The consequences of such competition may seriously jeopardize the business or completely destroy the attacked organization. 


\section{Economic consequences of corruption}

Given that corruption is a broad social problem, its consequences can have a great impact on the economic development of a country. On the other hand, corruption affects economic development in the sense that it slows it down. The greater the corruption, the less opportunity for economic progress. Corruption can still in some situations "lubricate the economic machine", and that is when a bad, or the kleptocratic state administration, imposes harmful regulation and thus puts obstacles in the way of normal business. In other words, corruption is not always and everywhere a negative phenomenon. Of course, the best way to eliminate not only corruption, but also its harmful effects, is to abolish bad and harmful regulation (Begovic, Mijatovic, 2007: 105).

The consequences of corruption in any area are great. They are most often grouped into several basic ones: a decline in economic efficiency, a decline in the volume of foreign investment and the impossibility of economic development. The question is, what is the most common consequence of corruption? It seems that this is a decline in the economic efficiency of the country, because in this way, social welfare is also reduced. Instead of developing new products and providing new types of services, instead of perfecting the offer and competing with the biggest competitors, entrepreneurs are dealing with how and when to bribe. Crime is becoming an industry.

How dangerous corruption is for society and the state is best illustrated by Peter Eigen, a member of the international non-governmental organization Transparency International: "Where politics, ie the public sector and the economy, are mixed, where public and strong personal interests are vaguely intertwined, it is only a step towards corruption.”(P. Eigen, 1999).

Also, one of the frequent problems that come to the fore is the threat to state sovereignty and the authority of state power, the violation of democratic values and public institutions, which ultimately harms the state system. On the other hand, in conditions of legal uncertainty and developed corruption, the interest of foreign investors in investing in those countries is decreasing. When analyzing the consequences, it should always be borne in mind that corruption may be the result of inefficient functioning of many institutions of the system, but it can also result in even less efficiency of the institutions of the system as a whole.

\section{Analysis of privatization of agricultural land in Serbia}

The accelerated privatization of the land in Serbia began within the framework of a broader process, i.e. the social and property transformation from a socialist to a capitalist social order. Privatization was most often presented as the best solution for the economy, which was damaged by the civil wars in the former Yugoslavia in the 1990s, looting carried out by the then ruling regime, sanctions by the international community and the NATO bombing in 1999. With privatization, the new owners would very often launder the money gained from criminal activities or would be interested only in acquiring attractive real estate, but not in preserving the production program, which led to a large number of fired workers and destroyed companies. 
The government formed after the parliamentary elections in May 2012, began the process of reviewing privatizations and arrests of responsible persons, which in a way officially recognized the criminal aspect of that process, which the public has been pointing out for years. However, the responsibility of the competent institutions, which is primarily reflected in the fact that they did not control the origin of the money that entered the legal flows through privatization, or whether the new owners maintain the continuity of production, has not yet been examined.

Although there was no basis for that in the then valid Constitution, the privatization that began in 2001 first de facto abolished social property, as a specific feature of Yugoslav communism until then. Social property was created by working or investing part of the salaries of employees or cooperatives and thus de facto emerged as cooperative, "but for political and legal reasons it was managed as social property" (Gulan 2012: 25). The 2006 Constitution defines a social property in this way, both agricultural enterprises and socially owned land became the subject of privatization. Privatization left drastic consequences in this case as well: in 253 privatized agricultural enterprises over 65,000 agricultural workers were laid off, more than 400,000 hectares of state and cooperative agricultural land have been transferred to private hands, and about 60 contracts, or one in four privatizations, have been annulled. In the process of privatization of agricultural enterprises, numerous illegalities have been committed in state and cooperative ownership, vaguely defined regulations regarding land ownership (Djukic, 2016: 285).

Privatization of agricultural companies and combines such as "Ratkovo", "Srpski Miletic", "Backi Brestovac", "Zmajevo", "Backi Maglic", "Lovcenac", "AK Subotica", "Mali Idjos" and others, the Agency for privatization did not determine what constitutes the capital that is the subject of the sale, nor did it allocate state and cooperative agricultural land during the sale. In that way, after the privatization in the Real Estate Cadastre, the buyers changed the form of ownership, i.e. the registration of private ownership on cooperative and state property. The Real Estate Cadastre Service of the Republic Geodetic Authority, on the basis of sales contracts and certificates from the Agency of the price paid, changed the form of ownership from public and cooperative to private property (Djukic, 2015: 286). It is obvious that the Privatization Agency did not legally validate the privatization of agricultural combines, i.e. companies, because it did not determine whether they have the right to use agricultural land that was in public and cooperative ownership. In that way, the land was not excluded from his property before privatization. Such a change in the form of ownership had no legal basis, because the contract on the sale of social capital transferred only the social capital of the subject of privatization, while only the right of use could be obtained on the state and cooperative property, but not ownership, because legal predecessor had none either. In addition, the Privatization Agency did not sufficiently provide measures for the protection of the property of the subject of privatization, timely control of the execution of sales contracts, through contracts concluded in privatization. This led to the collapse of those companies, the dissatisfaction of the workers, the reduction of the company's assets, the closing down of all or some parts of the company. The contracts were terminated 
only when the property of the subject of privatization was completely devastated. All this indicates that the privatization of agricultural enterprises and combines has not been well implemented, i.e. that privileged individuals have been enabled to acquire real estate, especially land under extremely favorable conditions.

As the extent of this appropriation in cooperative and state ownership is not known, the Anti-Corruption Council sent a request to the Privatization Agency to provide information on the total number and names of agricultural enterprises and plants that were privatized, on the total land area owned by privatized entities, about the status of property owned by agricultural enterprises and combines at the time of sale, the amount of the purchase price as well as whether the price shows the value of agricultural land. The Agency did not submit all the requested data to the Council with the explanation that it would submit them in a later period. (Report on state and cooperative land in the privatization process, Anti-Corruption Council, 2012). The Council also recommended to the Agricultural Land Administration of the Ministry of Agriculture to obtain from the Republic Geodetic Authority and the Cadastre Service of certain municipalities where real estate is located, data on changes in cadastral conditions on that land after privatization, as well as changes in state and cooperative ownership, so it could be determined whether the registration of property rights on state and cooperative property to the buyers of social capital was performed, on the basis of the privatization contract, and whether the registration changed the form of ownership.

The legal basis for the transfer of state, cooperative and even social property is also debatable. "Thus, for example, there are opinions that agricultural land as a public good of public interest could not and cannot be the subject of privatization." (Popov, 2013: 35). Namely, lands in the state and cooperative ownership have their owner, and agricultural combines had only the right to use it, but not the right of ownership that they could transfer to new owners. However, in the period of self-governing socialism, cooperative property was transformed into social property, and with the renewal of cooperatives, its legal status was largely not restituted, so it was treated as social in the privatization process. The situation is similar to social property, which was an expression of the socialist socioeconomic order of the institute sui generis and abolishing the factor of alienation of the working class from the means of production, so in the earlier philosophical-ideological concept its privatization would be heresy. To make this legal nonsense even more complex, the concept of privatization is contrary to the basic legal principle of derivative, translational acquisition of rights - nemo plus iuris ad alium transferre potest quam ipse habet. (Avramovic N., Stankovic M. 2020: 1034).

Serbia has pledged to allow foreigners to buy agricultural land four years after the entry into force of the Stabilization and Association Agreement (SAA) with the EU. By August 2012, all EU member states except Lithuania had ratified the SAA with Serbia. For the Agreement to enter into force it must be ratified by all member states and that such an unfavorable deadline for the sale of land agreed in the interest of tycoons who want to sell land they bought cheaply in privatization to rich foreign corporations as soon as possible, based on a large difference in prices of quality land on the Serbian http://ea.bg.ac.rs 
and European markets ((Freedom Movement, Workers 'and Peasants' Organization, Transparent Institute-TNI, 2013). Many countries in the region have agreed on a much longer deadline after which the sale of land will be allowed, while some have banned the sale. The privatization and consolidation of land owned by a small number of people who come to the land very cheaply aims at market speculation with the land (Gulan, 2012:26).

Analyzing the ownership of agricultural land in Serbia, we can conclude that the largest Serbian landowners together have more land than the area of individual countries or cities. Only the four largest Serbian owners own more than 100,000 hectares of land, and they are individually stronger than the largest European landowners. At the very top are the owner of the "Irva Group" with nearly 30,000 hectares, the owner of "Delta" with 25,000, the owner of "MK Komerc" who owns 24,000 hectares in Serbia, and the owner of the meat industry "Matijevic" with 16,000 hectares. Far behind them, for example, is the "Victoria Group" with about 6,000 hectares. However, it should be noted that all this land is not owned by them, but a good part was leased from the state. Because, when they bought combines, they contained a part of the state land that remained with them to cultivate (produce). However, their "ranches" are larger than the state of Liechtenstein, which has an area of about 160 square kilometers or 16,000 hectares. They are individually larger than Novi Sad, which has an area of 235 square kilometers or 23,500 hectares. This, however, only applies to the land they and their companies bought. But there is also land bought by their close associates and family members (Anti-Corruption Council Report, 2011).

Although the Law on Agricultural Land prohibits the sale of agricultural land to foreign persons, with the privatization of agricultural companies, foreigners, by registering their company as domestic, have already become owners of agricultural land in Serbia. Thus, IT, the Croatian tycoon and the owner of "Agrokor", bought "Frikom" and reached another 1,000 hectares, and with the "Diamond" oil mill, another 4,200 hectares. He cultivates a total of about 6,000 hectares. The Hungarian company "Hajdu Avis" from Debrecen bought an agricultural property "Sloboda "from Perlez with 1,500 hectares of land owned, and after four years resold it, of course with a profit. The Irish fund "Baltic Prosperite" caused a lot of noise in the public when it bought agricultural goods "Panonija"(near Backa Topola), PIK "Feketic" and "Vojvodina" from Backi Brestovac. By buying shares in these three factories, the company from Ireland got the right to manage 10,500 hectares. The first foreigner to discover that if you establish a company in Serbia you can buy agricultural land (unofficially) is Andrew Hunter, who bought "Jaksicevo" in Srpska Crnja in 2005, with 1,000 hectares for 245 million dinars through the company "Cornwell” (Djukic, 2016: 288). 
Table 1. The largest owners (foreigners) of agricultural land in Serbia

\begin{tabular}{|c|c|}
\hline OWNER - COMPANY & AREA IN HECTARES \\
\hline "Agrokor", "Frikom", "Dijamant" & 6.000 \\
\hline "Hajdu Avis" - Debrecin, Hungary & 1.500 \\
\hline $\begin{array}{c}\text { "Baltik prosperite"- Ireland, partner with: "Panonija", } \\
\text { "Feketic" i "Vojvodina" }\end{array}$ & 10.500 \\
\hline "Kornvel" - Endru Hanter, partner with "Jaksicevo" & 1.000 \\
\hline
\end{tabular}

Source: Anti-Corruption Council of the Government of the Republic of Serbia.

For example, in Denmark you cannot become a landowner if you do not have a certain level of education and proof that you have lived in the villages for 25 years without interruption (Gulan, 2010).

After the agrarian reform carried out in Yugoslavia after the end of the Second World War, which set a maximum of 10 hectares of land, and the rest of the nationalized country was given to agricultural cooperatives and combines, the process of transition and privatization, which in Serbia was controlled by the World Bank and other international institution, land becomes only one of the potentials for profit generation through export-oriented intensive industrial production on large land areas. Although accelerated industrialization after the Second World War, significantly reduced the rural population and led to its large migration (when 8 million people moved from villages to cities in the SFRY in half a century), in the current period of high unemployment and deindustrialization caused by privatization, the state should protect agriculture and its potentials in creating a sovereign, self-sustaining society in the interests of large and multinational capital. In the period of economic sanctions in the 1990s, the importance of agriculture in providing the basic living needs of the population came to the fore. According to research by UNICEF and OCHA (UN Office for the Coordination of Humanitarian Affairs), the mortality rate at the time of the sanctions did not increase significantly, primarily due to domestic agriculture and pharmaceutical production, thanks to which Serbia was not dependent on imports (Economic sanctions, Health, and Welfare in the Federal Republic of Yugoslavia, 1999-2000). As the Serbian pharmaceutical industry was almost completely destroyed in the privatization process, and agriculture became a field of big capital speculation, it is clear that the privatization process is fundamentally deeply directed against the interests of the population to ensure its existence through creating a sovereign, self-sustaining society (Djukic, 2016: 290).

The former president of the Anti-Corruption Council, the late Verica Barac, characterized the privatization process and the role of international institutions with the following words: "The law on privatization was made according to the concept of the World Bank and is based on the ideas of liberal economy. Institutions, property, process, and the origin of money are not important, only privatization is important. Through the privatization of socially-owned enterprises, more than 400,000 hectares of state and cooperative agricultural land have passed into private hands." Although by law, agricultural land cannot be privatized, through the registration of state and cooperative 
land as socially owned, hundreds of hectares of high-quality agricultural land ended in private hands. This was done by keeping the cooperative agricultural land as socially owned, although according to the Agricultural Land Act of 1992 and 1997, the entire land had to be transferred from social to cooperative ownership before privatization. Land in ownership of cooperatives presented as social property was sold, and these privatization programs were approved by the Privatization Agency, and thus, according to some data, 214,105 hectares of cooperative and more than 200,000 hectares of state land disappeared. An illustrative example is "Ratkovo", where 160 hectares of state agricultural land are reported and the official data of the Republic Geodetic Authority say that there were 413 hectares (Djukic, 2016: 291).

When it comes to the privatization of the largest and most important companies and agricultural land in Vojvodina, the buyers of agricultural plants and land were in some cases controversial businessmen's, and as in other cases in the privatization of agricultural land, the Privatization Agency and other state institutions did not have check of any kind, as well as the origin of the money when buying agricultural plants and cooperatives. In this context, we will mention the companies that were privatized in Vojvodina, namely: "Mladi borac", "Jedinstvo" from Gajdobra, "Backa" from Sivac, "Agrobacka" from Bac, "Zobnatica" (near Backa Topola), etc. A glaring case is also the privatization of the company "Mladi borac", which was bought for only 32 million dinars (36,000 euro), in six annual installments, with 360 hectares of land. Also, we cite the example that the company "Backa" from Sivac was privatized for 85 million dinars, with 37,000 hectares of agricultural land, under the irrigation system and with infrastructure facilities (Anti-Corruption Council Report, 2011).

Table 2. Privatization of agricultural combines in Vojvodina

\begin{tabular}{|c|c|}
\hline OWNER - COMPANY & AREA IN HECTARES \\
\hline "Zobnatica" - near Backa Topola & 2.650 \\
\hline "Backa" - Sivac & 37.000 \\
\hline "Jedinstvo" - Gajdobra & 1.300 \\
\hline "Agrobacka" - Bac & 900 \\
\hline "Mladi Borac" & 360 \\
\hline
\end{tabular}

Source: Anti-Corruption Council of the Government of the Republic of Serbia.

The privatization of one of the best and most modern agricultural combines in Serbia, "Zobnatica", is very characteristic, so we will stick to this example. Namely, Belgrade Stud Farm "Zobnatica" near Backa Topola, it has existed for almost two and a half centuries and was valid for one of the most famous in this part of Europe. The agricultural estate of the same name was founded in 1945. It spreads over 2,650 hectares, its own and leased land has a pig farm, a slaughterhouse, a hotel with 20 double rooms and three suites, as well as two hotel restaurants with 350 and a chard with 400 seats. They are engaged in fish farming, catering and tourism. They have a 
hippodrome, sports fields, a museum of horsemanship and a stable with 75 horses. There is also a hunting ground of 2,537 hectares. Fans of sport fishing have at their disposal a lake of 250 hectares. At the time of privatization, there were 151 workers, and at the end of last year, 114 employees and business income of 389,411,000 dinars. The first sale of social capital in "Zobnatica" was on April 11, 2008. Five potential buyers participated in the auction, because the ad did not provide for qualifying conditions. The starting price was 161 million dinars (1.8 million euro), and the largest was offered by the NB (21 million euro). The second place with about 20 million euro is the Consortium of natural persons whose representative is V.S., and the third place is Zrenjanin's "Dijamant". According to the daily "Press", the state stopped the sale of NB, because the Administration for the Prevention of Money Laundering connected it with Lj.B. Namely, Hypo Alpe Adria Bank allegedly received an instruction from the Administration for Money Laundering not to participate in this transaction. The next day, the NB accused the bank of "unreasonably refusing to execute an order from its accounts and pay the Privatization Agency." As the buyer did not pay within eight days, the Agency terminated the contract, without giving a subsequent deadline, which was a legal obligation. The second place was taken by the Consortium of natural persons whose authorized representative V.S. did not respond to the invitation to sign the contract. It was speculated that behind the consortium was a controversial businessman (Djukic, 2016: 293).

"In the second advertisement, qualifying conditions are set, from which it is clear that the sale is set for a certain buyer," claims the Anti-Corruption Council and reminds that "Zobnatica" is a company whose main activity is agriculture and animal husbandry. However, in addition to that, the advertisement asked as a qualifying condition that the potential buyer must be a hotelier who owns a 4-star hotel (absurd that it cannot even have five stars). The Privatization Agency explains that it decided on qualifying conditions at the second auction due to the importance of the company, its activities, business success and location, and that such importance did not exist at the time of the first auction, which was held only six months ago. The consequences of the qualifying conditions set in this way were to eliminate competition, eliminate all potential buyers from the first auction and create opportunities for only one buyer to appear. "Zobnatica" was sold for a much lower price than the bids at the first auction, although the starting price was the same, around 1.8 million euro. The price of 1.8 million euro is unacceptably low, because the property at the end of 2006 (two years before the sale) is estimated at eleven million euro. There are 2,650 hectares of agricultural land in "Zobnatica", with the fact that, according to the Agency, the buyer cultivates 1,360 hectares, and the rest of about 1,000 hectares are leased to individuals. In addition to the land, there are about 163,000 square meters of office space, which includes a hippodrome, a pond, and numerous facilities (Anti-Corruption Council Report, 2011).

As the only participant in the second auction, the Consortium (PH from Greece and "New Company" from New Belgrade) bought 70\% of the social capital at a starting price of 1.8 million euro, which is the same as the investment program. The Greek is 
an authorized representative of the Consortium with a share of only $5 \%$. The founder of "New Company" is the offshore company "Northgate Finance" in Liberia. The Privatization Agency did not ask the Administration for the Prevention of Money Laundering to check the origin and flows of money. The Agency performed control of operations in the first year of privatization, and determined that business continuity was not ensured, because the realized income after privatization, they accounted for only 16.93 percent of revenues in 2008 (Anti-Corruption Council Report, 2011). With repeated control, three months later, the Agency again determined that the buyer does not meet the agreed conditions. And in addition to non-fulfillment of obligations, the contract was not terminated, but new deadlines were provided, they claim, according to the Anti-Corruption Council (Djukic, 2015: 294).

With the new owner, losses also arrived, so after the privatization, a loss of around 150 million dinars was recorded, which was made by the majority owner. On several occasions, in the first two years, small shareholders claimed and asked the state authorities to investigate all the circumstances of the privatization, but that question remained unanswered.

\section{Conclusion}

Understanding the importance of security for business success is a prerequisite for the development of security management, whose goal is to provide security to the community, especially important in the period of transition.

In the period from 2000 to 2009, Serbia was ruled by democratic political and financial elite. According to unofficial data, it is estimated that a total of about 128 billion dollars came to the country from abroad in that period, which is about 13,000 dollars per capita. Although this amount seems high, it obviously did not affect the growth of the real sector, and the population of Serbia did not seem to notice that money. The situation in the country is such that the real sector was practically destroyed through privatization, instead of, as the proponents of privatization methods claimed, going through a period of stagnation, and then started to grow. Declaratively, privatization was aimed at strengthening the economy, employment and income growth. Realistically, it served for a speculative redistribution of goods.

The disputed privatizations of agricultural land soon became the subject of investigation by the competent prosecuting authorities and, given the wide range of participants with the participation of responsible persons from some state institutions, a serious social problem awaiting a response from the judiciary. Deficient privatizations in agriculture thus followed a series of 24 disputable privatizations pointed out by the Anti-Corruption Council of the Government of the Republic of Serbia, which became the subject of interest of the European Parliament with a request for revision, based on suspicious reasons for termination of sales contract.

Based on that, members of the working group of the Criminal Police Directorate, Ministry of Internal Affairs, arrested officials and officials in the Privatization 
Agency, on suspicion that they participated in abuses during the sale of the company "Tehnomanija" and other companies. The criminal report also covers the former director of the Privatization Agency, who was also arrested for illegal sale of the "Port of Belgrade". In addition, the police and the prosecution filed other criminal charges and undertook other activities within their jurisdiction, in connection with the aforementioned disputed privatizations (Djukic, 2015: 291).

Privatization of companies in Serbia was certainly one of the biggest sources of corruption in our country. Out of a total of 2400 privatizations that were carried out in the mentioned period, 1070 ended in bankruptcy, and 620 privatizations were annulled, i.e. a quarter of the proceedings. The largest number of contract terminations took place in the period from 2008 to 2010. Although it was a reaction of the state to the illegalities, the annulment of privatization was not a useful reversible procedure that brings a return to the previous situation, because those companies in a short period of private ownership were further ruined by extracting capital and tunneling it to other companies. In such a situation, no one needs these companies anymore. The private sector does not want to buy them, and for the state they represent only an additional burden. Although Serbia is the regional leader in annulled privatizations, those owners can be counted on the fingers of one hand (but also those who enabled them to buy companies for small money and quickly ruin it), who had to be ruined and emptied due to non-compliance with the law firms return to state skirts. Not only the 24 privatizations that are being investigated at the request of the EU are disputable, but also about 600 other cases in which the state terminated the contracts, but unfortunately, as it has already been said, in most cases it was done too late. Such an approach brought us to the moment that the entire state was threatened by such privatization. Of all the privatizations, agricultural companies in Vojvodina went through the worst in that process. Laws that favored tycoons and classic examples of corruption left the state without 400,000 hectares of arable land, and the number of employees on agricultural lands was reduced more than ten times. In each of these cases, the same scenario of ruin was applied. Since, according to the law, they could not sell more than ten percent of the property, loans were taken that were not repaid, and the companies went bankrupt. This has been done for years, and the state generally observed it silently and reacted only when everything was over (Djukic, 2015: 273).

\section{Conflict of interests}

The authors declare no conflict of interest.

\section{References}

1. According to: Economic sanctions, Health and Welfare in the Federal Republic of Yugoslavia 1900 - 2000 [in Serbian: Prema: Economic sanctions, Health, and Welfare in the Federal Republic of Yugoslavia 1990-2000]. 
2. Anti - Corruption Council Report 2011, page 16-26. [in Serbian: Izveštaj Saveta za borbu protiv korupcije za 2011. godinu, str. 16-26].

3. Avramovic, N., \& Stankovic, M. (2020). Privatization of agriculture according to foreigners. Economics of Agriculture, 67(3), 1029-1039. https://doi.org/10.5937/ ekoPolj2003029A

4. Criminal Procedure Code of the Republic of Serbia, Official Gazette RS, 72/2011, 101/11, 121/12, 32/13, 45/13, 55/14, 35/19 Belgrade, Serbia. [in Serbian: Zakonik o krivičnom postupku Republike Srbije, ,Službeni glasnik Republike Srbije“ broj 72/2011, 101/11, 121/12,32/13, 45/13, 55/14, 35/19].

5. Daily “Dnevnik” from April 21, 2013. [in Serbian: Dnevni list „Dnevnik“ od 21. aprila 2013. godine].

6. Djukic, S. (2015). Causes, manifestations and economic consequences of corruption in Serbia" - a comparative analysis in developed countries and countries in transition, EDUCONS University, Faculty of Business Economics.

7. Djukic, S. (2016). Analysis of criminal acts of economic crime and crimes of corruption in the economy. Vojno delo, 67(5).

8. Djukic, S. (2016). Corruption in Serbia - theoretical and empirical analysis, University Business Academy in Novi Sad, Faculty of Law for Commerce and Judiciary in Novi Sad.

9. Dragisic, Z., (2014). Security Management, Belgrade, Faculty of Security. [in Serbian: Dragišić Z., (2014) Bezbednosni menadžment, Beograd, Fakultet bezbednosti].

10. Gulan B. (2010). Who cultivates Serbian land, Belgrade.

11. Gulan, B. (2012). Hasty privatization, Belgrade.

12. Mijalkovski, M. (2012). Terrorism and organized crime, Pirot, Pi-press.

13. Mijatovic, B. (2007). Review of the book Begovic Boris: Economic Analysis of Corruption, Center for Liberal - Democratic Studies, Belgrade, Retrieved from www.clds.org.yu/newsite/prikaz-knjige-Bole.pdf.

14. Movement for Freedom, a workers 'and peasants' organization fighting against land grabbing in Serbia (Text written for the publication on land grabbing by the Transnational Institute (TNI) January 2013. [in Serbian: Pokret za slobodu, radničko-seljačka organizacija koja se bori protiv otimanja zemlje u Srbiji (Tekst je pisan za publikaciju o otimanju zemlje Transnacionalnog instituta (TNI), januar 2013. godine].

15. Peter, E. (1999), "New Rules of the Game", Neewsweek (member of the international non-governmental organization "Transparency International"). [in Serbian: Peter, E. (1999), "New Rules of the Game”, Neewsweek (član međunarodne nevladine organizacije ,Transparency International”].

16. Popov, Đ. (2013). The Impact of Transition on the State of the Serbian Economy. Proceedings of the Faculty of Law in Novi Sad, 47(1), 28-37. 
17. Report of the Privatization Agency for 2011. According to: www.priv.rs - Official site of the Privatization Agency. [in Serbian: Izveštaj Agencije za privatizaciju za 2011. godinu. Prema: www.priv.rs — Zvanični sajt Agencije za privatizaciju].

18. Report on state and cooperative land in the privatization process, which was made at the end of 2012 by the Council for the Fight against the Corruption of the Government of the Republic of Serbia (For more details see the Report). [in Serbian: Izveštaj o državnom i zadružnom zemljištu u postupku privatizacije, koji je krajem 2012. godine sačinio Savet za borbu protiv korupcije Vlade Republike Srbije. (Detaljnije podatke videti u Izveštaju)].

19. Stajic, Lj. (2011). Fundamentals of Security Systems, Novi Sad, Faculty of Law in Novi Sad.

20. Stevanovic, O. (2012). Security Management, Belgrade, Criminal Police Academy. [in Serbian: Stevanović, O. (2012), Bezbednosni menadžment, Beograd, Kriminalističko-policijska akademija].

21. Veselinovic J., Djukic S., (2014) Analysis of legal and economical aspects precipitation weather derivates for serbian agricultural sector, Institute of Agricultural Economics, No.4, Belgrade. [in Serbian: Veselinović J., Đukić S., (2014) Analysis of legal and economic aspects of precipitation weather derivatives for Serbian agricultural sector, Časopis Ekonomika poljoprivrede, broj 4, Beograd]. 